\title{
Toxicology and Oral Glucose Tolerance Test (OGTT) of Thai Medicinal Plant Used for Diabetes control, Phyllanthus acidus L. (EUPHORBIACEAE)
}

\author{
Napapach Chaimum-aom ${ }^{1 *}$, Sanong Chomko ${ }^{2}$, Chusri Talubmook ${ }^{2}$
}

\section{Napapach Chaimum-aom ${ }^{1 *}$, Sanong Chomko², Chusri Talubmook ${ }^{2}$}

'Ph.D. Candidate, Faculty of Sciences, Kantarawichai, MahaSarakham 44150, Thailand.

${ }^{2}$ Faculty of Science, Kantarawichai, MahaSarakham 44150, Thailand.

\section{Correspondence}

Napapach Chainum-aom, Department of Biology, Faculty of Sciences, Maha Sarakham University 44150, Thailand.

Phone numbers +66-4374-2620

Facsimile numbers +66-4374-2620

E-mail address: Cnapapach@gmail.com History

- Submission Date: 20-09-2016;

- Review completed: 18-10-2016;

- Accepted Date: 06-11-2016.

\section{DOI : 10.5530/pj.2017.1.11}

Article Available online

http://www.phcogj.com/v9/i1

Copyright

(C) 2016 Phcog.Net. This is an openaccess article distributed under the terms of the Creative Commons Attribution 4.0 International license.

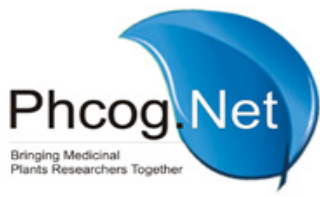

\begin{abstract}
Aim: The present study aimed to investigate toxicity and oral glucose tolerance test (OGTT) of Phyllanthus acidus leaf extract (PAE) on Wistar rat. Methods: PAE was prepared and administered orally to experimental animals used. The extract was tested for toxicity in rats at a dose of $0,1,000,1,500$ and $2,000 \mathrm{mg} / \mathrm{kg}$ body weight p.o once daily for 14 days. The hypoglycemic effects of PAE on normal rats and orally glucose-induced hyperglycemic rats were compared with distilled water and glibenclamide. A single dose $(250 \mathrm{mg} / \mathrm{kg}$ body weight) of PAE was administered and blood glucose level was obtained by pricking the tail vain using glucometer at time $-30,0,30,60,120$ and 240 minutes. Results: All doses of the extract did not exert any sign or symptom of toxicity and the dead rat was not found. The body weight, white blood cell (WBC), mean corpuscular volume (MCV), platelet (PLT), plateletcrit (PCT), mean platelet volume (MPV), platelet distribution width (PDW), blood chemistry, blood urea nitrogen (BUN), creatinine, alkaling phosphatase (ALP) and organ weight of liver were not significantly different between control and treated rats. However, red blood cell (RBC), hematocrit (HCT), lymphocyte (LYM), and hemoglobin ( $\mathrm{Hb}$ ) at a dose 1,500 $\mathrm{mg} . / \mathrm{kg}$ body weight were significantly lower than those in the control group. The blood glucose levels of PAE treated groups were not different with control and Glybenclamide treated. Conclusion: The findings of the present study can be concluded that the PAE are practically non-toxic at a lower dose.
\end{abstract}

Key words: Medicinal plant, Toxicity, Phyllanthus acidus, Diabetes, Blood glucose.

\section{INTRODUCTION}

In many part of the world, plants have formed the basis of sophisticated traditional medicine systems that have been in existence for thousands of years and continue to provide mankind with new remedies. ${ }^{1}$ The World Health Organization (WHO) estimated that $80 \%$ of people worldwide rely on herbal medicines partially for their primary health care. ${ }^{2}$

The South-East Asia region has a rich heritage of several systems of traditional medicine, many of which are popular use such as Malaysia, Borneo, Lao, Cambodia and Thailand

Have a long history of using medicinal plant that offers considerable pharmaceutical potential. ${ }^{3}$ Thai medicinal plants have long been used as a traditional source of diseases healing in Thailand. Several plants belonging to the family Euphorbiaceae have been utilized for medicinal purposes in Thai traditional medicine such as Pao Yai (Croton roxburghii N.P.Balakr.), Khuntongprayabhat (Suregada multiflorum (A.Juss.) Baill.),
Luk Tai Bai (P. amarus Schum\&Thonn.), Makhampom (P. emblica L.) and Mayom (P. acidus L.)

$P$. acidus is a small tree cultivated as a fruit tree in many Asian countries. It has a reddish flower and pale yellow or white fruit on the branches, which are edible, the testes sour. ${ }^{4}$ The leaves of this plant are food and recommended in folk medicine in Thailand for promoting and treating various diseases, including fever, piles, small pox, blood vomiting, itching, gum infection, ${ }^{5}$ antihypertensive, antipyretic, antiviral, antihepatotoxic, anti-inflammatory, ${ }^{6}$ dermatitis, menstruation fever, laxative, emetic, and diabetes. ${ }^{7-9}$ Some important phytochemical of the leaf includes hypogallic acid, kaempferol, gallic acid, quercetin, and adenosine. ${ }^{5,6}$ However, acute sub-acute toxicity and OGTT of $P$. acidus leaf extract has not yet been reported. The purpose of this research, therefore, was to examine the acute sub-acute and OGTT activities of $P$. acidus leaf extract in normal rats.
Cite this article : Chaimum-aom A, Chomko S, Talubmook C. Toxicology and Oral Glucose Tolerance Test (OGTT) of Thai Medicinal Plant Used for Diabetes controls, Phyllanthus acidus L. (EUPHORBIACEAE). Pharmacog J. 2017;9(1):58-61. 


\section{MATERIALS AND METHODS}

\section{Preparation of $P$. acidus extract}

Fresh mature leaves of $P$. acidus were collected from Roi Et, Thailand and identified by the Plant Varieties Protection Division, Department of Agriculture, Ministry of Agriculture and Cooperatives, Thailand. A voucher specimen is deposited in the Department of Biology, Faculty of Science, Mahasarakham University, Thailand (Code: MSU-Sci/PA 001). The leaves were collected and dried in an oven at a $50 \mathrm{C}$ for $45 \mathrm{~h}$. The dried leaves were powdered and extracted with $80 \%$ ethanol for 7 days. The extract obtained was filtered through a layer of Whatman No.1 filter paper and evaporated in a rotary evaporator (Heidolph Laborota 4000 , Germany) followed by a freeze dryer (Christ Alpha 1-4, Germany) to get a powder. The powder was stored at $-20^{\circ} \mathrm{C}$ until use.

\section{Animals}

Male albino Wistar rats weighting 150-200 g, which is purchased from the National Laboratory Animal Centre (NLAC), Mahidol University, Thailand. The rats were housed under standard environmental conditions (at $25 \pm 2^{\circ} \mathrm{C}, 40-60 \%$ humidity with 12 -h light/12-h dark cycle). ${ }^{10}$ All animals were given a standard laboratory diet with access to water ad libitum. The experimental protocol and the experiments performed on the rats were approved by the Institutional Animal Care and Use Ethic Committee, Mahasarakham University, Thailand (License No. 0004/2011).

\section{Acute toxicity test}

Eight of the test animals per group were fasted overnight $(12 \mathrm{~h})$ and weighed. Test doses of PAE were calculated in relation to the body weight of every fasted animal and administered on a doses of extract 0,1000 1500 and $2000 \mathrm{mg} / \mathrm{kg}$ respectively. The animals were regularly and individually observed for behavioral changes and general toxicity signs after dosing for the first $24 \mathrm{~h}$, with special attention being given during the first $4 \mathrm{~h}$. Thereafter, observation was continued daily for a total of 14 days. Mortality, body weights and food consumption were recorded.

\section{Sub-acute toxicity test}

Male Wistar rats, 8 per group, were treated orally with PAE daily for 14 days. $P$ acidus ethanolic leaf extract administered at 0, 1000, 1500 and $2000 \mathrm{mg} / \mathrm{kg}$ respectively. Mortality, body weights and food consumption haematological values and renal and hepatic functions were recorded.

\section{Oral glucose tolerance test (OGTT)}

The Oral Glucose Tolerance Test (OGTT) was performed on overnight fasting normal rats. Distilled water, PAE $(250 \mathrm{mg} / \mathrm{kg})$ and glibenclamide (2 $\mathrm{mg} / \mathrm{kg}$ ) were administered to three groups of rats, respectively. Glucose $(2 \mathrm{~g} / \mathrm{kg})$ was fed $30 \mathrm{~min}$ after pretreatment with distilled water, PAE and glibenclamide. Blood glucose levels were measured at $-30,0$, $30,60,120$, and $240 \mathrm{~min}$ after glucose load to access the effect of extract on blood glucose levels of the glucose loaded animals. The blood glucose was measured using blood glucose test strips and glucometer (Accuchek Adventage II; Roche, Germany).

\section{Statistical analysis}

All data were expressed as mean \pm standard error of mean (SEM). Statistical analysis was carried out using F-test (One-Way ANOVA) followed by a Scheffe's test. The criterion for statistical significance was at a $p$-value less than 0.05 .

\section{RESULTS AND DISCUSSION}

\section{Acute toxicity}

The limit dose of $2000 \mathrm{mg} / \mathrm{kg}$ did not cause mortality or any sign and symptom of acute toxicity in the three rats dosed for a short period (48 h) and long period (14 days). Percentage increase in body weight and average food intake of control were not different with PAE.

\section{Sub-acute toxicity}

The sub-acute toxicity in this study revealed that the rats fed by oral the dosed of 0,1000, 1500 and $2000 \mathrm{mg} / \mathrm{kg}$ PAE. There were no signs and symptoms of sub-acute toxicity during the 14 days. No mortality was seen in any of the treatment groups during the course of the study. Table 1, shown a body weight of the rats treated with PAE. There were no significant differences in body weight between the control 1000, 1500 and 2000 $\mathrm{mg} / \mathrm{kg}$ PAE treated. The result obtained on food intake is presented in Table 1 . There was a significantly decreased in $1500 \mathrm{mg} / \mathrm{kg}$ and $2000 \mathrm{mg} / \mathrm{kg}$ treated compared to control group.

Table 2 shows the organ weight of heart, lung, liver, kidney and gastrointestinal tract in rats administered with PAE. The heart, lung, kidney and gastrointestinal tract of the rat were significant differences $(\mathrm{P}<0.05)$ compared with control rats (Table 2). There was a significantly decreased in $1000 \mathrm{mg} / \mathrm{kg}, 1500 \mathrm{mg} / \mathrm{kg}$ and $2000 \mathrm{mg} / \mathrm{kg}$ treated with the weight of lung and $1500 \mathrm{mg} / \mathrm{kg}$ and $2000 \mathrm{mg} / \mathrm{kg}$ treated for kidney compared to control group. However, the organ weight of heart at the doses of $1000 \mathrm{mg} / \mathrm{kg}$ and $2000 \mathrm{mg} / \mathrm{kg}$ and gastrointestinal tract at the doses of $1000 \mathrm{mg} / \mathrm{kg}$ were significantly increased $(\mathrm{P}<0.05)$ from those in control rats $($ Table 2). The result exhibited no significant differences except for a red blood cell (RBC), hematocrit (HCT) in a dose of $1500 \mathrm{mg} / \mathrm{kg}$ and lymphocyte $(\mathrm{LYM})$ in a dose of $2000 \mathrm{mg} / \mathrm{kg}$ were significantly decreased $(\mathrm{P}<0.05)$ compared with control rats (Table 3 ). The renal and hepatic functions of $P$. acidus extract including BUN, creatinine and ALP were not significant in this study (Table 4).

\section{Oral glucose tolerance test (OGTT)}

Oral Glucose Tolerance Test, the blood samples were analyzed for glucose content at $-30,0,30,60,120$ and 240 minutes, respectively. The blood glucose levels of PAE $(250 \mathrm{mg} / \mathrm{kg})$ treated groups were not significant with control and Glybenclamide treated at a -30, 0, 30, 120 and 240 minutes. The blood glucose levels at 60 minutes in PAE and Glybenclamide treated lower than normal group.(Table 5)

\section{DISCUSSION}

In Thailand, medicinal plants have become famous in healthcare and some have been falsely considered as safe as they are obtained from natural sources. Therefore, toxicity study is required not only to identify the further range of doses in animal studies but also to explain the probable clinical signs evoked by the test compounds under investigation. ${ }^{11}$ The results obtained from the acute and sub-acute toxicity study showed that the PAE demonstrated high safety margin since the animals tolerated up to $2000 \mathrm{mg} / \mathrm{kg}$ body weight of the extract orally. No significant differences were found in the body weight among normal rats. In addition, in the food intake sub-acute toxicity in the treated groups was decreased between normal rats. The assumption might be PAE were increased feed conversion efficiency in rats. Hematological values were decreasing differentiation of RBC, HCT and LYM in normal and PAE treated. The reduction in RBC, HCT and LYM indicated that the extract in higher doses was toxic to circulation cell. ${ }^{12,13}$ Organ weight in general has been accepted as a valuable readout in toxicological study..$^{14,15,16}$ The current study shows heart, lung, kidney and gastrointestinal tract of the rat were significant differences $(\mathrm{P}<0.05)$ between treated and control rats. 
Table 1: Percentage increase in body weight and food consumption in acute and sub-acute toxicity studies of P. acidus leaf extract

\begin{tabular}{ccccc}
\hline Treatments & Control & $1,000 \mathrm{mg} / \mathrm{kg}$ & $1,500 \mathrm{mg} / \mathrm{kg}$ & $2,000 \mathrm{mg} / \mathrm{kg}$ \\
\hline Acute toxicity & & & & \\
Initial (g) & $180.00+3.13$ & $180.00+2.67$ & $183.13+8.81$ & $181.38+8.00$ \\
Final (g) & $205.75+1.99$ & $203.38+2.25$ & $210.75+7.03$ & $210.00+7.01$ \\
\% bw. increase & $14.52+2.08$ & $13.02+1.07$ & $14.93+2.19$ & $16.11+2.63$ \\
Average food intake (g/day) & $10.06+0.20$ & $10.18+0.41$ & $9.81+0.11$ & $9.47+0.20$ \\
Sub-acute toxicity & & & & \\
Initial (g) & $218.38+4.39$ & $218.38+7.18$ & $221.00+8.12$ & $219.63+6.82$ \\
Final (g) & $225.00+6.48$ & $223.38+6.24$ & $220.00+8.07$ & $206.88+8.34$ \\
\% bw. increase & $3.60+0.99$ & $3.01+0.95$ & $0.00+0.00$ & $0.00+0.00$ \\
Average food intake (g/day) & $10.36+0.20^{\mathrm{a}}$ & $9.68+0.46^{\mathrm{a}}$ & $5.36+1.17^{\mathrm{b}}$ & $7.43+1.01^{\mathrm{b}}$ \\
\hline
\end{tabular}

The values represent the mean + SEM within the same row followed by the different superscript letters (a- b) are significantly different at the $\mathrm{p}<0.05$.

Table 2: Organs weight (100 $\mathrm{g}$ body weight) in sub-acute toxicity studies of $P$. acidus extracts

\begin{tabular}{ccccc}
\hline Treatments & Control & $1,000 \mathrm{mg} / \mathrm{kg}$ & $1,500 \mathrm{mg} / \mathrm{kg}$ & $2,000 \mathrm{mg} / \mathrm{kg}$ \\
\hline Heart $(\mathrm{g})$ & $0.19+0.05^{\mathrm{b}}$ & $0.29+0.09^{\mathrm{a}}$ & $0.19+0.02^{\mathrm{b}}$ & $0.21+0.05^{\mathrm{ab}}$ \\
Lung (g) & $0.46+0.10^{\mathrm{a}}$ & $0.28+0.01^{\mathrm{bc}}$ & $0.19+0.03^{\mathrm{c}}$ & $0.34+0.09^{\mathrm{b}}$ \\
Liver (g) & $2.01+0.51$ & $2.44+0.12$ & $2.34+0.30$ & $2.11+0.32$ \\
Kidney (g) & $0.49+0.07^{\mathrm{a}}$ & $0.42+0.03^{\mathrm{ab}}$ & $0.41+0.05^{\mathrm{b}}$ & $0.38+0.01^{\mathrm{b}}$ \\
Gut (g) & $3.37+0.44^{\mathrm{b}}$ & $4.46+0.68^{\mathrm{a}}$ & $3.24+0.38^{\mathrm{b}}$ & $3.28+0.68^{\mathrm{b}}$ \\
\hline
\end{tabular}

The values represent the mean + SEM within the same row followed by the different superscript letters (a-c) are significantly different at the $\mathrm{p}<0.05$

Table 3: Haematological values of rats in sub-acute toxicity studies of $P$. acidus extracts

\begin{tabular}{ccccc}
\hline Parameters & control & $1,000 \mathrm{mg} / \mathrm{kg}$. & $1,500 \mathrm{mg} / \mathrm{kg}$ & $2,000 \mathrm{mg} / \mathrm{kg}$ \\
\hline RBC (x10 $)\left(\mathrm{cell} / \mathrm{mm}^{3}\right)$ & $8.36+0.13^{\mathrm{a}}$ & $8.11+0.96^{\mathrm{a}}$ & $7.35+0.18^{\mathrm{b}}$ & $7.77+0.19^{\mathrm{ab}}$ \\
HCT (\%) & $47.10+0.72^{\mathrm{a}}$ & $46.38+0.40^{\mathrm{a}}$ & $41.41+1.14^{\mathrm{b}}$ & $44.00+0.93^{\mathrm{ab}}$ \\
MCV (fl) & $56.31+0.39$ & $57.18+0.68$ & $56.40+0.30$ & $55.31+0.87$ \\
RDW (\%) & $10.95+0.14$ & $11.55+0.15$ & $11.10+0.22$ & $10.90+0.08$ \\
WBC (x10) (cell/ $\left./ \mathrm{mm}^{3}\right)$ & $5.05+0.63$ & $4.73+0.97$ & $3.61+0.38$ & $3.91+0.47$ \\
LYM (\%) & $85.78+2.30^{\mathrm{a}}$ & $87.44+1.45^{\mathrm{a}}$ & $78.34+4.49^{\mathrm{ab}}$ & $63.91+6.19^{\mathrm{b}}$ \\
MON (\%) & $2.92+0.69$ & $0.85+0.17$ & $2.80+1.02$ & $2.01+1.83$ \\
EOS (\%) & $0.41+0.11$ & $0.29+0.06$ & $1.39+0.49$ & $1.13+0.24$ \\
BAS (\%) & $1.53+0.51$ & $0.84+0.28$ & $5.03+2.02$ & $8.89+3.23$ \\
NEU (\%) & $8.42+0.93$ & $10.83+1.65$ & $11.15+3.15$ & $25.65+7.32$ \\
PLT (mm $)$ & $404.62+43.53$ & $535.00+73.62$ & $417.62+89.64$ & $504.75+71.41$ \\
PCT (\%) & $0.24+0.02$ & $0.33+0.04$ & $0.25+0.14$ & $0.29+0.04$ \\
MPV (fl) & $6.10+0.10$ & $5.85+0.23$ & $5.71+0.14$ & $5.67+0.09$ \\
PDW(\%) & $15.76+0.32$ & $15.51+0.26$ & $15.53+0.25$ & $15.96+0.32$ \\
Hb (gm/dl) & $16.60+0.23^{\mathrm{a}}$ & $16.57+0.15^{\mathrm{a}}$ & $15.30+0.29^{\mathrm{b}}$ & $15.90+0.28^{\mathrm{ab}}$ \\
\hline
\end{tabular}

The values represent the mean + SEM within the same row followed by the different superscript letters (a-b) are significantly different at the $\mathrm{p}<0.05$. 
Chaimum-aom et al.: Toxicology and Oral glucose tolerance test (OGTT) of Thai Medicinal Plant

Table 4: Renal and hepatic functions of rats in sub-acute toxicity studies of $P$. acidus extracts

\begin{tabular}{ccccc}
\hline Treatments & Control & $1,000 \mathrm{mg} / \mathrm{kg}$ & $1,500 \mathrm{mg} / \mathrm{kg}$ & $2,000 \mathrm{mg} / \mathrm{kg}$ \\
\hline BUN $(\mathrm{mg} / \mathrm{dl})$ & $28.55+3.86$ & $31.40+6.86$ & $30.73+4.18$ & $26.63+5.05$ \\
Creatinine $(\mathrm{mg} / \mathrm{dl})$ & $0.68+0.13$ & $0.74+0.42$ & $0.65+0.14$ & $0.72+0.13$ \\
ALP (U/l) & $60.25+5.82$ & $74.75+16.79$ & $78.87+15.19$ & $66.75+19.19$ \\
\hline
\end{tabular}

The values represent the mean + SEM within the same row followed by the different superscript letters

$(\mathrm{a}-\mathrm{b})$ are significantly different at the $\mathrm{p}<0.05$.

Table 5: The end of oral glucose tolerance test (OGTT) result.

\begin{tabular}{ccccccc}
\hline \multirow{2}{*}{ Treatment } & \multicolumn{7}{c}{ Blood glucose levels (mg/dl) } \\
\cline { 2 - 7 } & -30 & 0 & 30 & 60 & 120 & 240 \\
\hline control & $82.17+3.12$ & $81.17+4.07$ & $148.83+7.33$ & $127.83+7.24^{\mathrm{a}}$ & $112.17+7.63^{\mathrm{a}}$ & $83.17+3.16$ \\
P. acidus $(250 \mathrm{mg} / \mathrm{kg}$ b.w.) & $80.17+3.95$ & $79.33+3.57$ & $122.67+8.43$ & $97.50+7.85^{\mathrm{b}}$ & $91.50+4.96^{\mathrm{b}}$ & $77.50+3.99$ \\
Glybenclamide & $76.17+0.60$ & $84.00+2.05$ & $121.00+10.47$ & $98.67+5.38^{\mathrm{b}}$ & $90.83+3.30^{\mathrm{b}}$ & $80.83+3.22$ \\
\hline
\end{tabular}

The values represent the mean + SEM within the same column followed by the different superscript letters $(a-b)$ are significantly different at the $\mathrm{p}<0.05$.

However, the PAE treated showed no effects on renal (BUN, creatinine) and liver functions (ALP) in normal rats. The literature review also be documented that the hepatotoxicity in the rat has already been reported..$^{17,18}$ The findings of the present study can be concluded that the ethanolic leaf extracts of $P$. acidus are practically non-toxic at a lower dose. However, further studies are needed to confirm long-term toxicities. The oral glucose tolerance test (OGTT) is a widely used to evaluate apparent insulin release and insulin resistance in various clinical settings. ${ }^{19}$ For Oral Glucose Tolerance Test, the blood samples were analyzed for glucose content at $-30,0,30,60,120$ and 240 minutes, respectively. The single dosed study of PAE, doses at $250 \mathrm{mg} / \mathrm{kg}$ produced no significant hypoglycemic effect in normal rats. It's was compared with Glibenclamide has been used for many years to treat diabetes and stimulates insulin secretion.

\section{CONCLUSION}

The findings of the present study can be concluded that the ethanolic leaf extracts of $P$. acidus are practically non-toxic at a lower dose which one $2,000 \mathrm{mg} / \mathrm{kg}$. A study in OGTT showed that the P. acidus reduced blood glucose levels not different Glybenclamide treated. The single dosed study of $P$. acidus leaf extract, doses at $250 \mathrm{mg} / \mathrm{kg}$ produced no significant hypoglycemic effect in normal rats.

\section{ACKNOWLEDGEMENTS}

The authors gratefully acknowledge the Department of Biology, Faculty of Science, Mahasarakham University and the Research Institute, Mahasarakham University for partial financial support.

\section{REFERENCES}

1. Fakim G. Medicinal plants : Traditions of yesterday and drugs of tomorrow. Mol Aspects Med. 2006;27(1):1-93. http://dx.doi.org/10.1016/j.mam.2005.07.008; PMid:16105678

2. Motaleb MA, Hossain MK, Sobhan I, Alam MK, Khan NA, Firoz R. Selected medicinal plants of Chittagong hill tracts. IUCN (International Union for Conservation of Nature), Dhaka, Bangladesh; 2011;1.

3. World Health Organization. Review of traditional medicine in the South-East Asia region. New Delhi; 2004;1.

4. Habib R, Rahman M, Mannam A, Zulfiker AH, Uddin ME, Sayeed MA. Evaluation of antioxidant, cytotoxic, antibacterial potential and phytochemical screening of chloroform extract of Phyllanthus acidus. Int J Appl Biol Pharm. 2011;2:420-7.
5. Jain NK, Lodhi S, Jain A, Nahata A, Singhai AK. Effects of Phyllanthus acidus (L.) Skeels fruit on carbon tetrachloride-induced acute oxidative damage in livers of rats and mice. J Chinese Integr Med. 2011;9(1):49-56.; http://dx.doi. org/10.3736/jcim20110109

6. Vidya S, Ramesh A, Meghana D, Nazzer SK. The nephroprotective activity of methanolic extracts of Phyllanthus acidus leaves against gentamycin-induced nephrotoxicity in experimental rodents. Int J Pharm Sciences. 2013;5(4):209-13.

7. Sousa M, Ousingsawat J, Seitz R, Puntheeranurak S, Realado A, Schmidt A, An extract form the medicinal plant Phyllanthus acidus and its isolated compounds induce airway chloride secretion : A potential treatment for cystic fibrosis. Mol Pharmacol. 2007:71(1):366-76. http://dx.doi.org/10.1124/mol.106.025262 ; PMid:17065237

8. Leeya $Y$, Mulvany MJ, Emerson F, Queiroz C, Marston A, Hostettmann $K$ Jansakul C. Hypotensive activity of an n-butanol extract and their purified compounds from leaves of Phyllanthus acidus (L.) Skeels in rats. Eur J Pharmacol. 2010;649(1):301-13. http://dx.doi.org/10.1016/j.ejphar.2010.09.038; PMid:20868659

9. Unander DW, Webster GL, Blumberg BS. Records of usage or assays in Phyllanthus (Euphobiceae) Subgenera isocladus, kirganelia, cicca and emblica. J Ethnopharmacol. 1990:30(3):233-64. http://dx.doi.org/10.1016/0378-8741(90)90105-3

10. Silambujanaki P, Chitra V, Soni D, Raju D, Sankari M. Hypoglycemic activity of Stachytarpheta indica on stroptozotocin induced wistar strain rats. Int J Pharm Tech Res. 2009;1(4):1564-7.

11. Kumar P, Suba V, Ramireddy B, Srinivas BP. Acute and sub-acute (28 day) oral toxicity studies of ethanolic extract of Celtis timorensis leaves in rodents. Glob J Med Res. 2014;14(3):7-13.

12. Tehmina $Q$, Khadija F, Shemaila S. Effect of thiamine on glycemic control in diabetic rats. Ann Pak Inst Med Sci. $201 ; 7(4)$ :213-6.

13. Szkudelski T. The mechanism of Alloxan and Streptozotocin Action in B-cell of the rat pancreas. Physiol Res. 200;50:536-46.

14. Barua A, Acharya J, Ghaskadbi S Goel P. The relationship between fasting plasma glucose and $\mathrm{HbA} 1 \mathrm{c}$ during intensive periods of glucose control in antidiabetic therapy. J Theor Biol. 2014;363:158-63. http://dx.doi.org/10.1016/j. jtbi.2014.08.020; PMid:25158164

15. World Health Organization. Use of glycated haemoglobin $(\mathrm{HbA} 1 \mathrm{c})$ in the diagnosis of diabetes mellitus. Geneva ; 2011:25.

16. Healtcare Improvement Scotland. Management of diabetic; A national clinical guideline ; 2010:170.

17. Daisy P, Azhagu SB, RaJathi M. Antihyperglycemic effects of Phyllanthus extracts in alloxan-induced diabetic rats. Int J of Pharma Sci. 2009;1:261-4

18. Hemmingsen B, Lund S, Gluud C, Vaag A. Almdal T, Hemmingsen C, Wetterslev J. Intensive glycaemic control for patients with type 2 diabetes: systematic review meta-analysis and trial sequential analysis of randomized clinical trials. Brit Med J. 2011;343:6898. http://dx.doi.org/10.1136/bmj.d6898; PMid:22115901 PMCid:PMC3223424

19. Stuvoll M, Jarvien HY, Mitrakou A, Haeften TV, Pimenta W, Renn W, et al. Use the oral glucose tolerance test to assess insulin release and insulin sensitivity. Diabetes Care. 2000;23(3):295-301. http://dx.doi.org/10.2337/ diacare.23.3.295 